\title{
Study on the Images of the Code Hero Fighting Alone in Hemingway's Works
}

\author{
Xin Zheng \\ School of Foreign Languages, Shanxi Normal University, Linfen 041000, China
}

\begin{abstract}
As is known to us, as one of the most distinguished novelists in America, Hemingway is a profound writer for his simple writing style and the image of unyielding men in his famous works. The present study aims to uncover the image of the code hero fighting alone, which will make us have a good understanding of his works more deeply. Therefore, the present paper will choose his four masterpieces. The main characters always display a typical image, that is, "code hero", which shows "grace under pressure". In particular, Hemingway further probes into the themes, including men confronting with great challenges and struggling alone all the time, showing firm determination and courage when men face up to the defeats, and living with "grace under pressure" in The Old Man and the Sea. Therefore, it is obvious that the main character Santiago is regarded as the most typical code hero in literary creation.
\end{abstract}

Index Terms - Hemingway, code hero, grace under pressure

\section{INTRODUCTION}

As we all know, Ernest Hemingway is considered to be one of the important representatives of Lost Generation in the $20^{\text {th }}$ century. In the people's eyes, Hemingway is not only a myth in the current society, but also a myth in American literature. More importantly, he is actually a glamorous literary hero whose writing style and personal life are much more similar than any other writers. Hemingway gradually develops a distinct style of his own. To some extent, he writes all his life about one typical theme- "grace under pressure." Therefore, based on Hemingway's personal life experience and social background, this paper aims to explore the typical images of code hero fighting alone in his works.

In fact, we can find that Hemingway's inner world is essentially more or less chaotic and meaningless, in which men always fight alone against a force that he does not even have a better understanding. He becomes aware that however hard men struggle against the force, men come into being a strong sense of confusion and despair; however, Hemingway's heroes possess what Bertrand Russell defines "despairing courage". This kind of courage enables a man to act like a real man so that one person can show his dignity in face of difficulties. This kind of despairing courage is the intrinsic quality that all of Hemingway's code heroes act in obedience to. With regard to "code hero", Stanley Cooper (1996) comments that he would endure. The protagonists would insist on a ritual of action. This is the "Hemingway code" which emerges in all his books. With the characteristics of endurance, pride and courage, such as Jake and Santiago, they exhibit their courage filled with their own manhood. The Hemingway's code hero is a well-accepted concept in its time. Hemingway has successfully created this distinct image, which the readers of that time wish.

This paper will make a brief analysis of Hemingway's code hero fighting alone in the society at that time. As for us, it is necessary to study the features and spirits of code hero so that in a moment of personal crisis, we should fight against them to the end in spite of the pain, and show great dignity. It is the right and positive attitude that we should harbor towards our life.

\section{THE BACKGROUND INFORMATION}

The background information is essential for us to study Hemingway's code hero because it exerts profound influences on writer's attitudes towards life and his code hero. It provides some fundamental elements for us to analyze the code hero. Hence, this paper will introduce the social background that inextricably connects with Hemingway's works. There are three sections, including the social background, the literary trend of that time and the important phrase "the lost generation".

\section{A. Social Background}

Compared to the previous eras, it has marked tremendous changes at the beginning of the $20^{\text {th }}$ century. All of things have undergone an increasingly dramatic reform and transformation. Especially the sudden outburst of the First World War has a great influence on the everyday life of American people. More and more people have lost confidence towards life and society. They do not know how to pursue the meaningful life.

When it refers to Hemingway's life, he was born in the suburb of Chicago. When he grew up, he also lived in a turbulent period during which the World War I broke out when many young volunteers joined in the war, which is called 
"a war ends all wars". His life is so active and adventurous but filled with troubles and frustration. Confronting with the cruel and fierce social condition, there is no denying that the wars affect Hemingway a lot. Through his works, we can realize that he suffers so much which is brought about by the war deeply. He became to lose hope of the destiny of the human beings.

With regards to the background of Hemingway's code hero, Hemingway's novels are well accepted worldwide when first appeared. This is partly because he has created a fresh type of fictional characters whose attitude towards social life is extremely attractive to the people since the 1920s. The Hemingway's hero is a man who moves from one love affair to another, who participates in wild game hunting, who enjoys bullfights, who is embroiled in all the so-called manly activities. The average readers at this time identified with Hemingway's code hero because that is what they dreamed of.

\section{B. The Literary Trends of That Time}

Except for the social background above-mentioned, literary trends of that time also greatly reflects the social circumstances and the author's inner world.

During the aftermath of wars, people had no confidence or purpose to the life and society due to the spiritual breakup of modern civilization. Order and rational outlook seem to no longer stand for the world. People's life is paradox and full of chaos. Therefore, in face of such a changed circumstance, the writer's task is to develop new techniques and to explore new and divergent themes that could make a break with the past. Then a dominant thought-modernism appeared in the $20^{\text {th }}$ century.

Modernism is a complex and diverse international movement in all the creative arts. It rejects the established rules, traditions and convention (Elliott, 1988). Meanwhile, it seeks innovation and flexibility. Therefore, combined with the background of the times, writers in the field of literature have tendency of expressing the frustration caused by the capitalist system, modern war and mechanized civilization (Elliott, 1988). Many famous works focus on expressing the loss of certainty and optimism in social progress and anxiety about the future. The modernism gives great impacts on Hemingway and other writers.

\section{Lost Generation}

The Lost Generation is correlated with the modernism. It is a term that is firstly used by Gertrude Stein, who is one of the leaders of this group. Generally speaking, on the one side, they make efforts to describe the Post-World War I. For another thing, because the WWI had destroyed the innocent and simple ideas and this generation had lost beautiful sense of the calm idyllic past, many good young men had gone to the war and died, or returned damaged both physically and mentally. Their moral faith is no longer valid - they are lost. Hence, this famous term displays a sense of moral loss or spiritual void.

It is well-known that the three important representatives of Lost Generation are F. Scott Fitzgerald, Ernest Hemingway and Dos Passos. They are cut off from the old values, but unable to put up with the new era because modern civilization tends to madness (Chen, 2013). Especially, almost all of Hemingway's works deal with the disillusionment of "the lost generation". Meanwhile, Hemingway's life is reflected in his writing, that is to say, his creation source stems from his personality and his early experiences. No matter what the protagonist is doing, such as drinking, bullfighting, or battle, Hemingway is actually writing about himself. Therefore, as we all see, first of all, the period of his early life is reflected in the stories about Nick Adams. Furthermore, the experience during World War I is a mirror of plots in A Farewell to Arms. Last but not least, Hemingway also creates the character Santiago, the classical image of the "code hero", which stems from his experiences of fishing. This novel shows Santiago's undefeated spirits. On the basis of his own situation, almost all of his heroes are members of "the lost generation". They wander pointlessly and restlessly. At the same time, they are aware that the world is crazy, meaningless and futile. In a word, Hemingway's life is reflected in his famous works. There are many preliminary cues that can be found.

\section{HEMINGWAY's CODE HERO}

In chapter three, based on the social background and the trend of literature, this paper will present the features of Hemingway's code hero that can contribute to the analysis of the four famous works in this study.

From collecting many materials, in this paper, "grace under pressure" can be short for the "code". It is an ideal set of beliefs and attitudes, essentially a mode of self- regard. When heroes are in trouble in a hostile and destructive environment, this faith can enable them to take action and move on. In this paper, the word "hero" can mean not only "hero" but also "protagonist" in English. Therefore, this sort of code heroes possesses the pride and endurance. To be specific, firstly, code heroes have the ability to accept pain even loss, when loss cannot be avoided. Secondly, with the great courage code heroes have the pride that they try their best to tackle the difficulties. Lastly, code heroes take on great will to confront with the defeat or victory without complaining on one hand or boasting on the other.

In the past few decades, scholars have investigated relevant researches on Hemingway's works from different angles. The critical articles have studied Hemingway's works from the aspect of his cultural psychological structure, philosophical thinking tragic consciousness, nihilistic thought, death consciousness, the view on women and his code hero, etc.

A great number of critics come to recognize the common feature of Hemingway's code hero since the 1930s. Among 
the critics, Carlos Baker (1969) is the first to make an overall analysis of Hemingway and his novels. Then Scholar Philip Young (1966) originates the term, "Hemingway's code hero" and uses the term to describe Hemingway's hero. About the code hero, he is such a person who exemplifies certain traits of power, honor, courage and endurance, etc. $\mathrm{He} / \mathrm{She}$ is involved in tension and pain but never gives up. They always do one's utmost to move forward and seek the value of life. Therefore, after struggling what a man has happened and experienced make a person become a true man, who sticks to a hyper-masculine moral code. Ultimately the person has understood the real world by virtue of those code or beliefs. Similarly, among Hemingway's many enthusiasts in China, a scholar comments, "almost all his Hemingway's novels concern about the theme of grace or dignity confronted with the life's tragedy" (Wu, 2002, p.121). Therefore, many researchers have made an analysis on "despairing courage" that urges people to fight alone. Chang Yaoxin (1991) states, a code hero, based on Hemingway's opinion, must have "grace under pressure", should possess the following characteristics. The code hero has a clear orientation and knows what he is doing. For example, they can drink excessively but not sloppily, and cannot talk too much, especially about his accomplishments. He must have proper social skills.

Although various comments have been made on his theme, they can be roughly made a classification: one is the "code hero" who struggles all the time, displaying "grace under pressure"; the other is his thoughts of nothingness (Su, 2000) shown in the world of trauma, sleeplessness, loss and spiritual sterility in the universe. This man is the "code hero", according to Leonard Unger (1974), if he could attain it, he would have ability to live properly when the world has turned into violence, merciless, disorder, and misery, etc.

\section{TyPiCAl IMAGES OF CODE HERO IN HEMINGWAY’s WORKS}

Based on the social background and literary trend in chapter three, the present study will analyze tough guys or code hero in Hemingway's four masterpieces. They are The Sun Also Rises, A Farewell to Arms, For Whom the Bell and The Old Man and the Sea. At the same time, this chapter will attempt to conclude Hemingway's views on the Code Hero.

\section{A. Jake Barnes}

The Sun also Rise was published in 1926. There are strong youth elements in this book. Moreover, Hemingway has vividly described the pain and frustration that the war has brought to the young generation.

The features of Hemingway's code hero are clearly shown to the readers. At the beginning of his writing career, Hemingway's code hero is represented by Jake Burns in The Sun Also Rises. There is a group of expatriates in this novel, who has already lost the belief in the meaningless world. The cruel and absurd war has led to them disillusioned, alienated and even desperate (Chan, 1991). The protagonist, just like Jake Burns, lives in such a circumstance. Facing up with wound in the physical and mental aspects, Jake shows endurance, courage, and persistence in a barren spiritual world.

In detail, at the beginning of the story, Jake, like other people, lives in a dissolute and extravagant life. But they are lost in spirits. The reason is that men's destiny is completely changed by the modern life and social reform. A lot of people are compelled to leave their homeland. They wander or take part in wars. Therefore, their traditional value and religious faith gradually collapse. In this novel, we can realize that Jake is trying to come to terms with life despite his physical wounds. But in other aspects Jake is different from his jobless friends. Jake occupies his days with his job as a newspaper reporter. The nights become extremely difficult owing to his physical wound. Therefore, Jake always falls into endless pain. However, Jake has been moderately successful with everything until Brett reenters his life. He loves the heroine. Jake's love intensifies every time he meets her. But as for him, it is obvious that love seems to be impossible due to his physical wound, which makes their affection enters into a dilemma. Gradually the hopeless love gives not only Jake but also Brett great pain. As for Brett, she tries to find consolation by finding one lover after another in order to deal with the tragedy in her life. Having witnessed Brett's debauched behaviors, Jake gains additional pain. Brett's presence constantly reminds Jake of his physical wound, and thus gives him more emotional pain or pressure. Therefore, Jake Barnes regards the real life as a nightmare. The pain is so much that it leads Jack to looking at his body and crying. The only strength to encourage him to live on is that with any dignity he should fight alone. He comes to realize that the whole world is vanity of spirit. Hence, facing up to the adversity, human beings can only do little to fight the unknown universal forces. Jake sees barges pushed by the tug and the current condition with little control over their own movements. But unlike the barges, man can decide and choose how to accept the suffering, well or badly. That marks the difference between Hemingway's code hero and the crowd. Jake endures the pains with style and grace.

In a word, as for Hemingway's writing style, he does not make a comment and analyze the inner world of the character. He just describes and narrates the image of Jake in a simple way. Such a distinct style leaves a deep impression on readers. In another aspect, as for the symbolic meaning of the character, Jake Barnes is really a Fisher King in an Eliotic Waste Land. His physical impotence is a token of modern men's spiritual impotence. That is what Hemingway wants to deliver to us. Therefore, it is the most meaningful enlightenment by means of this novel.

\section{B. Henry}

A Farewell to Arms was actually a semi-autobiographical novel, which was firstly published in 1929 . The scene is set in the Italian campaigns. This novel displays the important events in the First World War. In fact, in Hemingway's 
opinion, war, which can destroy love and human nature, is an absurd action. What's worse, it leads to belief crisis. Generally speaking, because A Farewell to Arms shows how people like Henry come to behave the way they do, it is a supplementary specification to The Sun Also Rises.

In this novel, the protagonist-Henry is brave and emotional. $\mathrm{He}$ is always perusing order, reason and the significance of the human life. In the war, Henry shows respect to human nature. He can be regarded as a modern hero. Actually we make sense that Henry is not a war hero who kills people on the field of battle. However, he is a Hemingway's code hero, who fights alone with the trouble of human life.

Henry seeks for the truth of life at the cost of the happiness. He always attaches too much significance to the value of life. Hence, he is always disappointed by the daily basis, because the life is cruel in nature. There is no denying that Henry joins the army just for being far away from the dullness of the modern life, which stimulates Henry to hold the arms; again he is compelled by the chaos and cruelty of war to the arms of his lover. Love provides Henry with consolation, order and courage. However, he forgets that life is a war itself. In Hemingway's vision, the world is irrational, disordered and unexplainable (Du \& Xiao, 2006). Henry has experienced the disillusionment as the order and values that he has been searching for have been completely shattered. It seems that the only thing man can do is to subordinate both in war and peace life after the war. Nevertheless, Hemingway has always been read as essentially a pessimist about world which fills with failure and death.

From another level, this novel overall spreads the atmosphere of disillusionment. The protagonist's loneliness and hopelessness is expressed through the characterization of Henry in virtue of a kind of detachment from life.

The tragic destiny of failure and death of Hemingway's heroes reveals the modernists' deep tragic psychology towards future and human beings' endless fighting spirits. Hemingway with his code heroes never fears death and failure. For Henry, what makes he afraid of life is to live in a insignificant condition. In the war, when he is bombed in the war, Henry might have died, but he is the only one who is left to see more chaos in the world and suffers more from the tragedy of disillusionment of human life.

At the end of the novel, the dead does not disillusioned, whereas the left must suffer the anguish of disillusionment. Tragic expectations are permeated throughout the novel by means of Henry's meditations on life. Therefore, ample evidence demonstrates that Hemingway's tragedy is not the tragedy of death and failure; it is the tragedy of disillusionment.

\section{Robert Jordan}

For Whom the Bell Tolls was published in 1940. It is based on Hemingway's experiences during the Spanish Civil War and depicts a young American protagonist, named Robert Jordan. Although this novel is based on the background of the war, Hemingway does not describe the grand spectacle of the war. He just selects a very small angle to shape the image of Jordan. Besides, from the perspective of the theme, this novel takes Jordan as the core and gets rid of a pessimistic mood.

The image of Hemingway's hero, Robert Jordan, is assigned as an expert to bomb a bridge behind the Fascist line for the Republic's surprise attack. Hemingway shapes this character, who integrates into the society. In the process, Jordan encounters incidents one after another, which all make his tasks more and more difficult. However, Jordan devotes whole-heart to his task, facing death with courage. Therefore, the theme in this novel is full of spirits which is struggling for others. However, struggling for others - it is easy to say, but difficult to achieve. Some people seem to be extremely great, preparing for helping other people but lastly be testified to be very selfish. In the end, at the moment of dying or living in the war, Robert distinguishes himself from others. His great image as an international solider resisting fascist war and bravely paying his life should receive respect from all of us, which leaves no room for argument. Therefore, Jordan is endowed with noble qualities.

To be specific, Robert Jordan, who is an American young teacher teaching Spanish, could absolutely have lived his life in America far away from the Spanish war and taken no notice of it. However, he loves Spanish deeply, and it is impossible for him to see the Spanish people suffering from the war with folded arms. Therefore, Robert takes part in the Spanish civil war for the happiness and liberty of the Spanish people and struggles for the aim until the last minute of his life. His spirit should and could be memorized forever by Spanish people living in happiness now.

For another thing, war to love is what difficulty to friendship. On the fatal moment, everything hidden deeply would be spoken publicly, all veils would be thrown away and all lies would be exposed. In Robert's eyes, Maria is much more important than himself. The love turns his life to a new page. Love, struggling with the war, is beautiful but pitiful. To a large extent, just because of the cruelty of the war, the beauty of the love is given more lusters. Therefore, although the war prevents the love from getting a good result, it makes the love more moved than the usual ones.

All in all, in this book Jordan is only a quasi-Marxist and he does not really and totally believe in Marxism. But he carries out the task with resolution even it costs his life. The meaninglessness of the task makes his sacrifice more tragic and pathetic. Yet against the power and danger of the adversary, Jordan demonstrates great passion for life and courage in face of death. Jordan is a typical Hemingway's code hero: enduring physical and emotional pain, facing death with dignity.

\section{Santiago}

In the Hemingway's later years, he produced the short novel-The Old Man and the Sea in 1951, which gains his 
fame as a writer in the first rank. Therefore, Hemingway is praised for his powerful and distinct writing style.

It is necessary for us to make a comment on Santiago, who is regarded as a hero. Because the important qualities of Santiago, for example, nobility, confidence, dignity, courage and the remarkable personality, penetrate into people's mind. The protagonist_- Santiago, is a profound example. And then he is also a new type of code hero (Zhang, 2011). So it is necessary to understand the distinct features between Santiago and other code heroes. In this novel, owing to his physical demerits, Santiago displays powerful courage. Meanwhile, he tries his best to show dignity to conquer the troubles. After that, just like a moral superior, he is always full of sympathy and love. Sometimes he helps the boy and tells him his personal experience and skill. So gradually this boy also displays the image of code hero. We can see that this boy is full of courage, confidence and persistence in difficulties. Meanwhile, he shows his love to the others. All of these are good qualities. Last but not least, the content in this novel has offered us some preliminary cues and sheds light on his quality (optimistic, active and promising, etc). So from this level, he makes a new breakthrough compared with other heroes. Therefore, it is not exaggeration to say that Santiago makes us impressive and he is a real hero.

For the detail of this novel, Hemingway depicts Santiago, as an old man. From the appearance description, the old man turns to be too weak and thin to catch a big fish. So the feeling of sympathy towards Santiago arises spontaneously. In fact, Hemingway not only describes Santiago's weak and old appearance, but also tends to reflect his unyielding spirit. This point can be demonstrated by his eyes, which are not stuffy and even cheerful. This contrast clearly shows Santiago's real personality. On the other side, Hemingway uses the length of time (84 days) to reflect indirectly Santiago's traits. After a long period of time, a man cannot tolerate continuous failure, because to a greater extent, too much setbacks or failure will destroy a person's confidence, even strong will. However, in this novel, Santiago is unusual. From his viewpoint, nothing can defeat his will, although he is a poverty-stricken and lonely old man. Santiago always keeps the faith that he will not always be unfortunate. Therefore, the power that makes him persist in is that the hope for the future and the unyielding spirit to challenge his fate.

In brief, in The Old Man and the Sea, Hemingway vividly creates the distinct character of code hero. Santiago acts as a hero who deeply reflects Hemingway's own attitude towards life. That is to say, a person should go through the failure that is inevitable in everyday life, meanwhile, he should show dignity and grace under pressure. Santiago possesses persistence, self-confidence and resolution to get over various predicaments in his life. Even though he knows that he cannot win the battles, he still does his utmost to fight alone for the sake of displaying not only his dignity but also courage, bravery and skill. Consequently, it is obvious that Santiago gains our love and respect.

At last, it is necessary to mention the Santiago's famous saying, "A man can be destroyed but not defeated." This is the essence of the whole novel. This sentence comes to the point. It not only sums up the old man's character: his endurance, persistence and undefeated spirit but also points out the novel's theme and significance. As for us, these spirits give us enlightenment and encourage us to smile in the face of difficulties.

As presented above, there exist certain common features among the protagonists due to the fact that these characters share identical personalities and life experiences and that they bear similar attitudes towards society. More specific, they share the following characteristics:

From these four different novels, first and foremost, code heroes have great physical potential and powerful courage. Generally speaking, they are hurt in some way, but they are never defeated. Even if they may lose everything ultimately because they are mortal, they play the game honestly and passionately all the same. Furthermore, they are in possess of strong willpower with which they have the ability to restrain themselves and keep self-disciplined against the physical and emotional pain alone. They keep the emotion under control and show dignity when defeated and confront with death with silence. Besides, they are completely honest, keeping one's promise. They behave in this way: not just say something but take action, not always tell something but provide some suggestions. Last but not least, they are endowed with certain specialized skills, such as fishing, bull fighting, and hunting, etc. All in all, in the chaotic and meaningless world, men make a solitary struggle against a force that they may not understand. Later they become aware that they must end in defeat, no matter how hard they fights against it, engenders a sense of despair (Su, 2011). Finally, with their personal faith and endurance, the code heroes take a different ways of life, that is, "grace under pressure".

\section{CONCLUSION}

With regard to four important works of Hemingway, we have made a detailed analysis of code hero in Hemingway's works. Meanwhile, it is apparent that Hemingway's own personality and rich life experiences make him create these immortal works. He displays his own true feeling or outlook on life through the code hero, who shows human's willpower, courage and persistence to challenge the dreadful circumstance and keeps up great spirits to defeat the opponent.

To Hemingway, life is doomed to struggle, just like meeting various challenges. For one thing, he deems that whatever the result is, people have the ability to struggle against life. For another thing, even though he knows that sometimes it is no use of continuous struggle when human beings face the natural and mysterious forces, he still believes that human beings are not totally desperate in the cold world. Therefore, he encourages people to make efforts to do what they want to do. In this sense, Hemingway's attitude towards life is beneficial to individuals in today's society. Many people always make a complaint about the fate and the chance when people talk about daily trivia and face the troubles and setbacks in their life. In the course of complaining, they want to get the support from others. 
Without other's affiliation or alignment, they feel discouraged and hopeless towards life. Compared with the code hero, this is not the right attitude towards life. We should learn from Hemingway's code hero. A man should overcome the difficulties in life with courage, dignity and confidence.

In Hemingway's novels, man can be physically destroyed but never defeated spiritually. Hemingway's end is not a happy one, but the end of a person's life does not judge a writer. Hemingway's life is filled with death and violence, which gives Hemingway deep pain both physically and mentally. However, Hemingway gains a worldwide reputation and great success, which is mostly due to his talent and his courage. Code hero is the profound representative of Hemingway's works. In the most limited sense, it is an artistic mirror of Hemingway himself. Moreover, in a wider sense, it is the incarnation of American innocence. Code hero is the most representative one of the unique category of modern heroes that Hemingway has created. Several typical images make people impressive and keep in the mind everlasting. Therefore, it is indisputable to say that the images of code hero are bound to the milestone in the 20 th century in the literature.

\section{REFERENCES}

[1] Baker, C. (1969). Ernest Hemingway: A Life Story. New York: Charles Scribner's Sons.

[2] Chang Yaoxin. (1991). A Survey of American Literature. Tianjing: Nankai University Press.

[3] Chen Jiao.(2013). Looking at the "Lost Generation" from The Sun Also Rises. Modern Communication, 4, 77.

[4] Cooperman, S. (1996). Ernest Hemingway's The Old Man and the Sea. Beijing: Foreign Language Teaching and Research Press.

[5] Du Xiaohong \& Xiao Mingdan. (2006). Esthetic Value of Animal Symbols Raised in A Farewell to Arms. Journal of Nanchang University(Humanities and Social Sciences), 4, 115-119.

[6] Elliott, E. (1988). Columbia Literary History of the United States. New York: Columbia University Press.

[7] Gaggi, J. (1998). Hemingway and Nineteenth Century Aestheticism. London: U. M. I Research Press.

[8] Hemingway, E. (1977). A Farewell to Arms. London: A Division of the Collins Publishing Group.

[9] Hemingway, E. (1926). The Sun Also Rises. New York: Charles Scribner's Sons.

[10] Hemingway, E. (1997). The Old Man and the Sea. Shanghai: Foreign Literature Press.

[11] Hu Tiesheng. (1994). Elegance under Heavy Pressure--Comments on the Characters in Hemingway's Writings. Foreign Literature Studies, 1, 84-87.

[12] Lania, L. (1961). Hemingway, A Pictorial Biography. New York: Viking Press.

[13] Ma Ruixiang. (2003). The life and values of Santiago-Ernest Hemingway's The Old Man and the Sea. Journal of Shenyang University, 3, 88-89.

[14] Ni Fang. (2008). Elegance Under Heavy Pressure. Academic Journal of Nanjing Institute of Industry Technology, 1,32-33.

[15] Su Shunqiang. (2000). On Hemingway's Nihility Thought. Foreign Literature Studies, 1,131-135.

[16] Unger, L. (1974). American Writers: A Collection of Literary Biographies Volume II. New York: Charles Scribner's Sons.

[17] Wu Dingbai. (2002). An Outline of American Literature. Shanghai: Shanghai Foreign Language Education Press.

[18] Young, P. (1966). Ernest Hemingway: Reconsideration. University Park: Pennsylvania State Press.

[19] Zhang Yan. (2011). Code Heroes in Hemingway's Stories-A Critical Analysis on In Another Country. Overseas English, 10, $20-21$.

Xin Zheng was born in Taiyuan, Shanxi in 1993. She received her bachelor's degree in English from LvLiang University, Shanxi in 2016

She is currently a postgraduate studying for her master's degree and majoring in Foreign Linguistics and Applied Linguistics in Shanxi Normal University. Her research interests included sociolinguistics, second language acquisition and cognitive linguistics. 